\title{
Thermodynamic analysis of the reduction process of Colombian lateritic nickel ore
}

\author{
Sandra C. Díaz ${ }^{\mathrm{a}, \bowtie}$, Adriana Garcés ${ }^{\mathrm{a}}$, Oscar J. Restrepo ${ }^{\mathrm{b}}$, Misael A. Lara ${ }^{\mathrm{c}}$, Jesús E. Camporredondo ${ }^{\mathrm{d}}$ \\ ${ }^{a}$ Universidad Nacional de Colombia, Facultad de Minas, sede Medellín, Carrera 65 N $63-20$, Bloque 54 Medellín, Colombia \\ ${ }^{b}$ Universidad Nacional de Colombia, Facultad de Minas, Carrera 65 N²63-20, Bloque 54 Medellín, Colombia \\ 'Universidad Autónoma de Coahuila, Facultad de Ciencias Químicas, Blvd. V. Carranza s/n Col. \\ República Oriente C.P. 25280 Saltillo, Coah, México \\ ${ }^{\mathrm{d}}$ Universidad Autónoma de Coahuila, Facultad de Ingeniería Mecánica y Eléctrica, \\ Carretera 57 Km. 5, Ciudad Universitaria, 25710 Monclova, Coah., México \\ Corresponding author: scdiazb@unal.edu.co
}

Submitted: 11 June 2015; Accepted: 3 October 2015; Available On-line: 1 December 2015

\begin{abstract}
The Colombian nickeliferous laterites are minerals used for the nickel extraction by hydrometallurgical and pyrometallurgical processes. In this work the thermodynamic behaviour of three Colombian lateritic mineral samples are described, with contents of $1.42 \%, 1.78 \%$ y $2.04 \%$ of nickel, when they are subjected to the calcination and reduction processes. The mineral was characterized using $\mathrm{X}$ Rays Diffraction and $\mathrm{X}$ Rays Fluorescence, giving evidence of the presence of mineralogical species such as nepouite $\left(\mathrm{Ni}_{3} \mathrm{Si}_{2} \mathrm{O}_{5}(\mathrm{OH})_{4}\right)$, goethite $\left(\mathrm{Fe}_{2} \mathrm{O}_{3} \cdot \mathrm{H}_{2} \mathrm{O}\right)$, silica $\left(\mathrm{SiO}_{2}\right)$, antigorite $\left(\mathrm{Mg}_{3} \mathrm{Si}_{2} \mathrm{O}_{5}(\mathrm{OH})_{4}\right)$ and fosferite $\left(\mathrm{Mg}_{2} \mathrm{SiO}_{4}\right)$. The thermodynamic analysis was conducted using the software HSC Chemistry for Windows 5.1 and was focused in the quantitative determination of the chemical evolution of the mixture of these minerals with variable quantities of coal, in function of temperature. The results produced by the program showed, in the equilibrium, the feasibility of complete reduction of the nickel, and additionally, a considerable high percentage of reduction of iron oxides (up to $99 \%$ ) using ratio $\mathrm{C} / \mathrm{O} \approx 1$ at temperatures close to $1100^{\circ} \mathrm{C}$.
\end{abstract}

KEYWORDS: Ferro-nickel reduction; Nickeliferous laterite; Ratio C/O; Thermodynamic analysis

Citation / Cómo citar este artículo: Díaz, S.C., Garcés, A., Restrepo, O.J., Lara, M.A., Camporredondo, J.E. (2015) "Thermodynamic analysis of the reduction process of Colombian lateritic nickel ore". Rev. Metal. 51(4): e057. doi: http://dx.doi.org/10.3989/revmetalm.057

RESUMEN: Análisis termodinámico del proceso de reducción de minerales lateríticos de níquel colombianos. Las lateritas niquelíferas colombianas son minerales utilizados para la extracción de níquel mediante procesos hidrometalúrgicos y pirometalúrgicos. En este trabajo se describe el comportamiento termodinámico de tres muestras de mineral laterítico colombiano, con contenidos de 1,42; 1,78 y 2,04\% de níquel, respectivamente, cuando se someten a los procesos de calcinación y reducción. El mineral se caracterizó utilizando difracción de rayos $\mathrm{X}$ y fluorescencia de rayos $\mathrm{X}$, poniendo de manifiesto la presencia de especies mineralógicas tales como nepouita $\left(\mathrm{Ni}_{3} \mathrm{Si}_{2} \mathrm{O}_{5}(\mathrm{OH})_{4}\right)$, goethita $\left(\mathrm{Fe}_{2} \mathrm{O}_{3} \cdot \mathrm{H}_{2} \mathrm{O}\right)$, sílice $\left(\mathrm{SiO}_{2}\right)$, antigorita $\left(\mathrm{Mg}_{3} \mathrm{Si}_{2} \mathrm{O}_{5}(\mathrm{OH})_{4}\right)$ y fosferita $\left(\mathrm{Mg}_{2} \mathrm{SiO}_{4}\right)$. El análisis termodinámico se realizó utilizando el software HSC Chemistry for Windows 5.1, y el estudio se centró en la determinación cuantitativa de la evolución química de mezclas de estos minerales con cantidades variables de carbón en función de la temperatura. Los resultados obtenidos con el programa muestran, en el equilibrio, la posibilidad de reducción completa del níquel y un elevado porcentaje de reducción de los óxidos de hierro (hasta $99 \%$ ) empleando relaciones $\mathrm{C} / \mathrm{O} \approx 1$ a temperaturas cercanas a los $1100{ }^{\circ} \mathrm{C}$.

PALARAS CLAVE: Análisis termodinámico; Laterita niquelífera; Relación C/O; Reducción ferroníquel.

Copyright: (C) 2015 CSIC. This is an open-access article distributed under the terms of the Creative Commons Attribution-Non Commercial (by-nc) Spain 3.0 License. 


\section{INTRODUCTION}

Nickel is a strategic metal used in metallurgical industry as raw material in the production of stainless steel. Countries like New Caledonia, Japan, Russia, USA, Brazil, Greece, Cuba, Indonesia, Phillipines, Dominican Republic, Australia, Guatemala, Colombia, Yugoslavia, Venezuela and China have operations for the nickel extraction through pyrometallurgical route and hydrometallurgical route based on laterites of nickel (Dalvi et al., 2004). Laterites are the result of the land degradation promoted by climate changes and humidity exposition, among other geological factors (Rodríguez et al., 2009), in general the nickel content increases as increases the depth of deposit (Girgin et al., 2011). They can be classified in limonites or saprolites, based on the iron and magnesium ( Li, 1999; Dalvi et al., 2004; Oxley and Barcza, 2013) content and they are treated in a different ways, either by pyrometallurgical or hydrometallurgical processes. The most superficial layer and the base of the deposits have the lowest nickel contents $(<0.8 \%)$, the first layer is mainly composed by hematite and the second one, the deposit base, corresponds to the rock weathering. The zones of limonites and saprolites and their transition are the ones which show greater potential for the nickel extraction due to their metallic content, lower than $1.5 \%$ of $\mathrm{Ni}$, for limonites and higher to $1.5 \%$ in saprolites (Girgin et al., 2011).

Some lateritic nickel minerals which have a high content of magnesium shall be previously dehydrated, by pyrometallurgical route (Huang and Lv, 2011). One of the pyrometallurgical processes for the ferronickel production is the process Rotary Kiln- Electric Furnace (RKEF) (Rao et al., 2013). This processing route combines the calcination and the partial reduction of the iron and nickel oxides in a rotatory furnace, which product called calcine is then transformed in an arc electric furnace, the prevalent conditions in this reactor promote the reduction and fusion, getting a separated Fe-Ni alloy from the liquid slag.

The thermodynamic behavior of the nickeliferous laterites with low contents, carried to a pyrometallurgical process has been studied. There are works such as the of Pickles et al., (2013), they making a thermodynamic analysis based on the system $\mathrm{Fe}-\mathrm{Ni}-\mathrm{Co}-\mathrm{Mg}-\mathrm{Si}-\mathrm{O}-\mathrm{H}-\mathrm{S}-\mathrm{C}-\mathrm{Cl}$ in order to establish the effect of variables such as the temperature, sulphur and coal quantity, as well as chlorine additions for the nickel recovery (Pickles et al., 2013).

The nickel solubility is controlled by the thermodynamic activity of the slags, which has a great importance in the pyrometallurgy of nickel. The introduction of new processes and the trend towards the production of high-grade plants nickel industry, has been directed to increase the separation of the metal and slag during the melting phase (Ramírez, et al., 2008), this means an effective separation.
The current study is focused in the thermodynamic analysis of three lateritic mineral samples basically compound by iron oxide, nickel oxide and magnesium silicates, in form of nepouite $\left(\mathrm{Ni}_{3} \mathrm{Si}_{2} \mathrm{O}_{5}(\mathrm{OH})_{4}\right)$, goethite $\left(\mathrm{Fe}_{2} \mathrm{O}_{3} \cdot \mathrm{H}_{2} \mathrm{O}\right)$, silica $\left(\mathrm{SiO}_{2}\right)$, antigorite $\left(\mathrm{Mg}_{3} \mathrm{Si}_{2} \mathrm{O}_{5}(\mathrm{OH})_{4}\right)$ and fosferite $\left(\mathrm{Mg}_{2} \mathrm{SiO}_{4}\right)$. Behavior of mineral samples in the reduction process with carbon was determined using the "Equilibrium Compositions" HSC Chemistry for Windows 5.1 software module.

Starting from the present species, the most important reactions were analyzed in the process, the temperature was increased up to $1100^{\circ} \mathrm{C}$, for calcination and reduction processes. A closed system was established where the reduction atmosphere is self-generated due to the action of the thermal degradation of the added coal. The effect of the initial proportion of coal on the composition to the equilibrium of the resulting system was quantitatively determined, inferring proportionality with the reduction percentages of the relevant metals in the mineral.

As a starting point, Ellingham diagrams were made, in the range of characteristic temperatures the RKEF process, in order to evaluate the stability of the present species. Additionally the relevant transformations of the reaction heat were determined, such as the dehydration of the goethite to produce hematite and the reduction of the iron and nickel oxides.

\section{EXPERIMENTAL PROCEDURE}

\subsection{Characterization of minerals}

The species present in the nickel laterite minerals were identified and determined semi-quantitatively by Fluorescence Rays X (FRX) using a Philips PW 1404 X-Ray Spectrometer. It was also used an X Rays Philips PW 1729.

\subsection{Thermodynamic Simulation}

The thermodynamic analysis of the reduction process of the nickel lateritic minerals mixed with coal was conducted using the "Equilibrium compositions" module, which it is useful to calculate, in this study in particular, the evolution of the composition to the system equilibrium based on the variation of the coal concentration and temperature. The algorithm of calculation implemented in this option of the software is based on the free Gibbs energy minimization method.

The program entry data are the proportions of the system initial components, the species which potentially may occur and the size value and steps number of the independent variable, in this case a) coal proportion or b) temperature, for the ones which shall be calculated in a discrete way, the system concentrations in equilibrium. 
The thermodynamic analysis was conducted having into account the following considerations:

- The proportion of the initial components corresponds to the initial composition of the minerals. - It is assumed that is a system closed to the atmosphere

- It is assumed that the added coal is pure, therefore, it is related as carbon

- Granulometry is not had account, because it has kinetic and non-thermodynamical implications

The different systems analyzed consist on a mixture of laterite of nickel with coal, this last one is a component in the range from 3.75 to $7.59 \%$ in weight, such range of coal concentrations corresponds to a $\mathrm{C} / \mathrm{O}$ relation in the range of 0.66 to 1 , the oxygen was considered as the one contained in the iron and nickel oxides. Due to the temperature effect the metallic oxides become more unstable than the carbon oxides, resulting in the $\mathrm{Ni}$ and $\mathrm{Fe}$ reduction while carbon monoxide and carbon dioxide is generated.

$\mathrm{C} / \mathrm{O}$ is the ratio of added carbon related to oxygen that to be reduced. Ratio $\mathrm{C} / \mathrm{O}$ was worked stoichiometrically. For instance, sample 1 contain $5.42 \mathrm{~g}$ of oxygen in the $\mathrm{NiO}$ and $\mathrm{Fe}_{2} \mathrm{O}_{3}$, therefore, it added $5.42 \mathrm{~g}$ of carbon in order to stablish a ratio $\mathrm{C} / \mathrm{O}=1$.

A first approximation of the behavior expected from the system under study is obtained from the making of Ellingham diagrams ( $\Delta \mathrm{G}$ vs $\mathrm{T}$ ), and also using the mentioned software.

\section{RESULTS AND DISCUSSION}

\subsection{Characterization}

Content of $\mathrm{Ni}, \mathrm{Fe}, \mathrm{MgO}, \mathrm{SiO}_{2}, \mathrm{Al}_{2} \mathrm{O}_{3}$ and water in each sample was determined through the FRX elemental analysis technique. The results are shown in the Table 1 where is stressed the special importance of the Ni content which fluctuates between 1.4 and 2.0\%.

The XRD spectra gives evidence that the three lateritic mineral samples contain magnesium silicates in form of nepouite $\left(\mathrm{Ni}_{3} \mathrm{Si}_{2} \mathrm{O}_{5}(\mathrm{OH})_{4}\right)$ and iron in form of goethite $\left(\mathrm{Fe}_{2} \mathrm{O}_{3} \cdot \mathrm{H}_{2} \mathrm{O}\right)$, and they present silica contents as quartz $\left(\mathrm{SiO}_{2}\right)$, antigorite $\left(\mathrm{Mg}_{3} \mathrm{Si}_{2} \mathrm{O}_{5}(\mathrm{OH})_{4}\right)$, fosferite $\left(\mathrm{Mg}_{2} \mathrm{SiO}_{4}\right)$, among others. Nickel is associated to the structure in form of silicates. These results are presented in Fig. 1 ( $a, b$ and c), which correspond to each one of the samples.

TABle 1. Chemical analysis of Colombian lateritic minerals (wt, \%)

\begin{tabular}{lcccccc}
\hline Sample & $\mathbf{N i O}$ & $\mathrm{Fe}_{2} \mathbf{O}_{3}$ & $\mathbf{M g O}$ & $\mathbf{S i O}_{2}$ & $\mathbf{A l}_{2} \mathbf{O}_{3}$ & $\mathbf{H}_{2} \mathbf{O}$ \\
\hline M1 & 2.59 & 16.2 & 22.7 & 43.3 & 1.5 & 13.7 \\
M2 & 2.27 & 19.7 & 21.3 & 40.5 & 1.9 & 14.3 \\
M3 & 1.81 & 24.0 & 23.0 & 35.6 & 2.2 & 13.4 \\
\hline
\end{tabular}

\subsection{Thermodynamic analysis}

As a part of the thermodynamic analysis, Ellingham diagrams ( $\Delta \mathrm{G}$ vs $\mathrm{T}$ ) of the relevant mineralogical species contained in the studied samples were made. These kinds of diagrams show the stability ranges and thermodynamic instability of the species represented and eventually, it constitutes an indicator of the system behavior in terms of feasibility of the development of calcination and reduction reactions of the components of the studied mixtures.

The Ellingham diagram is shown in Fig. 2, it is a representation of the calcination process of the species present in the nickel lateritic minerals, it is observed the stability of some compounds which contain nickel, magnesium and silicon in form of hydrated silicates and on the other hand, the dehydration process of goethite is found, being transformed into hematite starting at $84{ }^{\circ} \mathrm{C}$. The reaction and energy associated to the change proceed as follows (Eq. (1)):

$$
\begin{aligned}
& 2 \mathrm{FeO}(\mathrm{OH}) \longrightarrow \mathrm{Fe}_{2} \mathrm{O}_{3}+\mathrm{H}_{2} \mathrm{O}(\mathrm{g}) \\
& \Delta \mathrm{H}_{84}{ }^{\circ} \mathrm{C}=54.479 \mathrm{KJ}^{\circ} \Delta \mathrm{G}_{844^{\circ} \mathrm{C}}=-0.316 \mathrm{~kJ} \mathrm{~mol}^{-1}
\end{aligned}
$$

The heat of formation shows that the transforming reaction of goethite to hematite is an endothermic reaction. It is important to emphasize that the calcination process is an operation which breaks down the complex mineralogical species into simple oxides with a homogeneous nature and susceptible to be reduced.

Additionally, it is observed that at $430{ }^{\circ} \mathrm{C}$ the decomposition reaction of the goethite through carbon is feasible with the $\mathrm{CO}_{2}(\mathrm{~g})$ generation as a stable product, presenting a $\Delta \mathrm{G}=-0.395 \mathrm{~kJ} \mathrm{~mol}^{-1}$

In the Fig. 2, it is evident the goethite instability in the presence of carbon above this temperature. At a temperature of $1140{ }^{\circ} \mathrm{C}$, the goethite in the presence of carbon monoxide becomes unstable, resulting in a $\Delta \mathrm{G}=-0.234 \mathrm{~kJ} \mathrm{~mol}^{-1}$. Also, in the Fig. 2 have taken into account the mineralogical species present in the mineral, therefore, the variation of Gibbs free energy is minimum. With the species identified in the mineral it is not possible carry out the reduction process, therefore, the calcination process is very important for homogenize the chemical composition.

The reduction reactions of iron and nickel oxides are favored when these are dissociated as decomposition product of the hydrated silicates through calcination previous to the reduction. The aluminum, silicon and magnesium oxides remain stables in the fusion process giving origin to the slag. In Fig. 3 an Ellingham diagram for a sample basically constituted by oxides formed in the calcination stage is shown. Reactions that predominate in this process are shown as follows (Eqs. 2, 3, 4 and 5):

$$
\begin{aligned}
& 3 \mathrm{Fe}_{2} \mathrm{O}_{3}+\mathrm{C} \longrightarrow 2 \mathrm{Fe}_{3} \mathrm{O}_{4}+\mathrm{CO}(\mathrm{g}), \Delta \mathrm{H}_{272.8^{\circ} \mathrm{C}} \\
& =123.97 \mathrm{~kJ} \mathrm{~mol}^{-1}, \Delta \mathrm{G}_{272.8^{\circ} \mathrm{C}}=-0.528 \mathrm{~kJ} \mathrm{~mol}^{-1}
\end{aligned}
$$



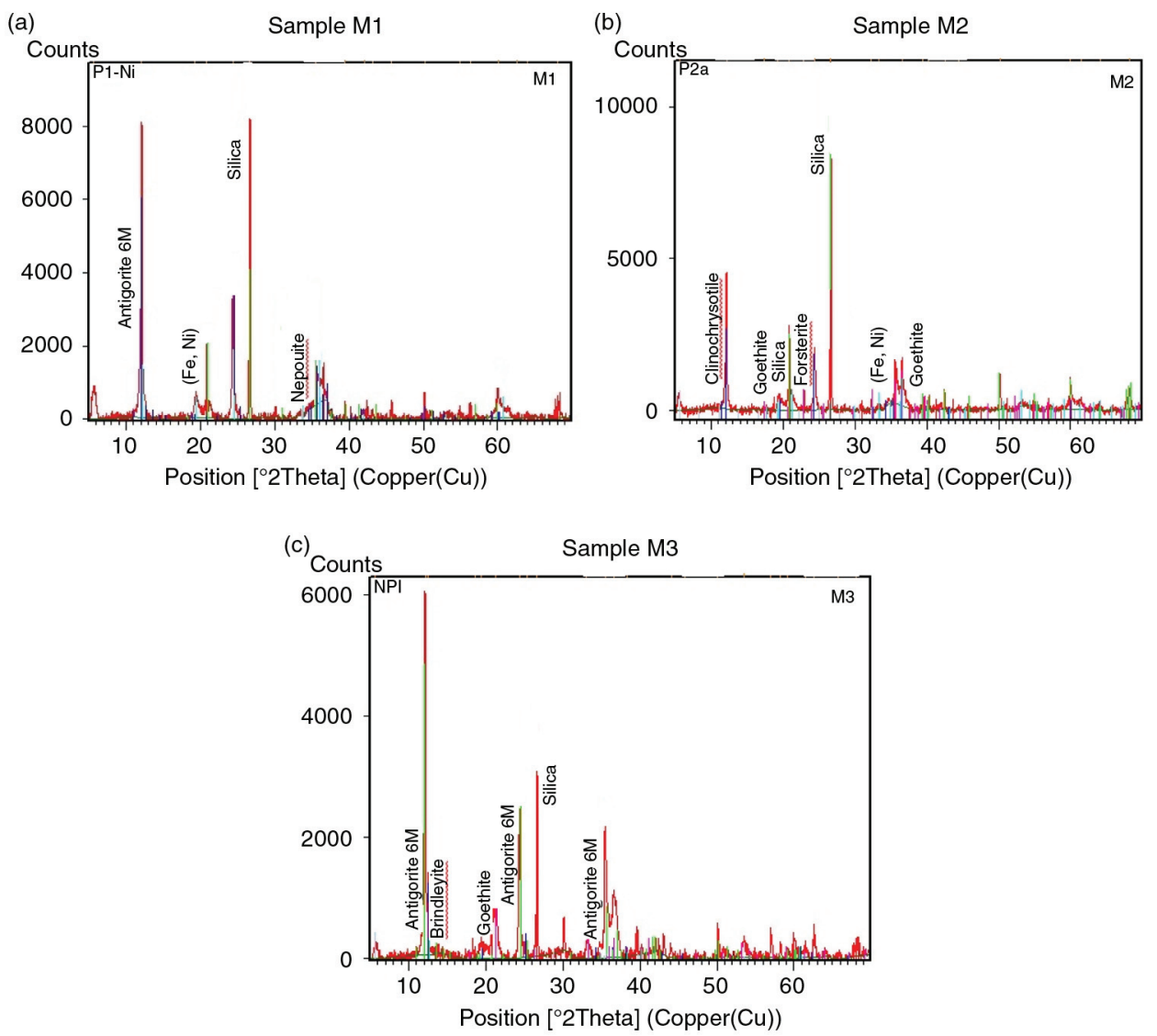

Figure 1. DR-X Spectra for the samples analyzed: a) M1, b) M2 and c) M3.

$\mathrm{Fe}_{3} \mathrm{O}_{4}+\mathrm{C} \longrightarrow 3 \mathrm{FeO}+\mathrm{CO}(\mathrm{g}), \Delta \mathrm{H}_{702.27^{\circ} \mathrm{C}}$

$=183.9 \mathrm{~kJ} \mathrm{~mol}^{-1}, \Delta \mathrm{G}_{702.27^{\circ} \mathrm{C}}=-0.308 \mathrm{~kJ} \mathrm{~mol}^{-1}$

$\mathrm{FeO}+\mathrm{C} \longrightarrow \mathrm{Fe}+\mathrm{CO}(\mathrm{g}), \Delta \mathrm{H}_{722.34}{ }^{\circ} \mathrm{C}$

$=152.5 \mathrm{~kJ} \mathrm{~mol}^{-1}, \Delta \mathrm{G}_{722.34^{\circ} \mathrm{C}}=-0.512 \mathrm{~kJ} \mathrm{~mol}^{-1}$

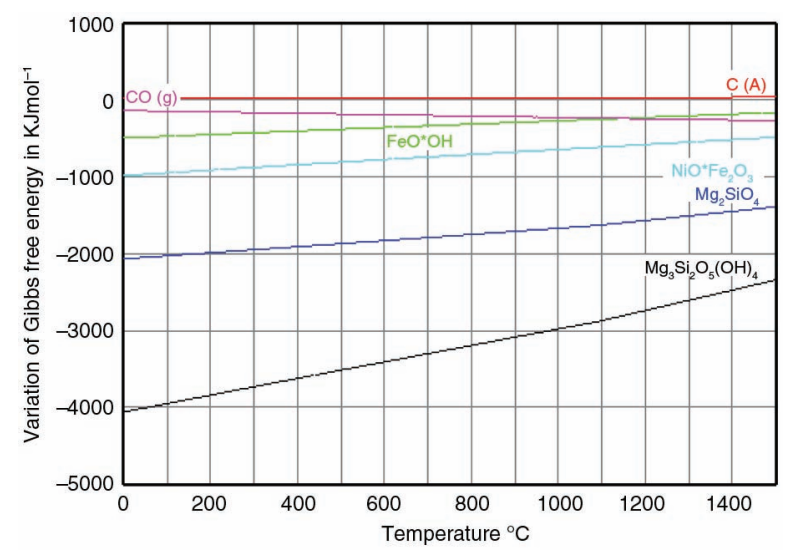

FIGURE 2. Ellingham diagram of the species contained in nickel lateritic mineral representing calcination and reduction processes up to $1500^{\circ} \mathrm{C}$.
$\mathrm{NiO}+\mathrm{C} \longrightarrow \mathrm{Ni}+\mathrm{CO}(\mathrm{g}), \Delta \mathrm{H}_{437.4^{\circ} \mathrm{C}}$

$=126.6 \mathrm{~kJ} \mathrm{~mol}^{-1}, \Delta \mathrm{G}_{437.4}{ }^{\circ} \mathrm{C}=-0.483 \mathrm{~kJ} \mathrm{~mol}^{-1}$

Ellingham diagram of the Fig. 3 shows that at a temperature of $420^{\circ} \mathrm{C}$ the $\mathrm{NiO}$ decomposes giving place to the reduction process with a $\Delta \mathrm{G}=-0.176 \mathrm{~kJ} \mathrm{~mol}^{-1}$. For $\mathrm{FeO}$ is obtained a $\Delta \mathrm{G}=-0.199 \mathrm{~kJ} \mathrm{~mol}^{-1}$ at $720^{\circ} \mathrm{C}$, approximately. As mentioned above, it can be conclude that the nickel oxide is more easily reducible than the iron oxide, and in addition, this last one should pass through three important reduction stages in the treatment of lateritic minerals.

Figures 2 and 3 are referred to the change in Gibbs free energy when the temperature increases. In Fig. 2 is shown mineralogical species present in samples of lateritic nickel ores to be worked. These species effectively, without a significant change of free energy, when in contact with gases such as $\mathrm{CO}$ and $\mathrm{CO}_{2}$. Also, in Fig. 2, it's important to note a calcination process to break the balance of the species shown in the diagram Ellingham

Additionally, is shown the transformation of goethite to hematite in the presence of heat. In Fig. 3, is shown the variation in Gibbs free energy with increasing temperature, involving oxides obtained 


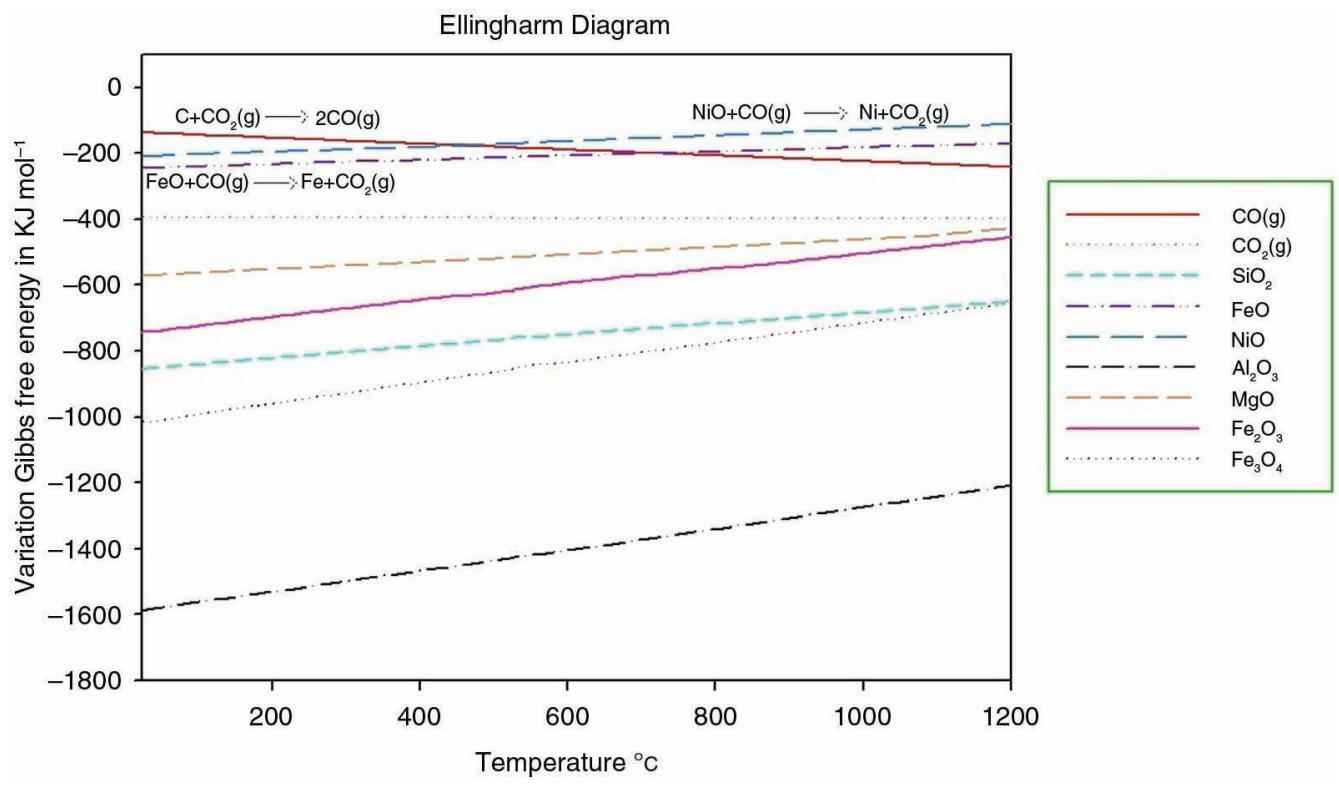

FIGURE 3. Ellingham diagram representative of the reduction of the species contained oxides such as calcination product of nickel lateritic minerals, range of temperatures $0-1200{ }^{\circ} \mathrm{C}$.

during calcination. Oxides are added carbon. The formation of $\mathrm{CO}$ and $\mathrm{CO}_{2}$ is observed.

The reactions of iron oxide and nickel oxide reduction are noted. Additional oxides like aluminium oxide, silicon oxide, and magnesium oxide do not have changes at temperatures of $1100{ }^{\circ} \mathrm{C}$. For this reason, it is noted the reactions that involving the nickel oxide, iron oxide and the reactions of the $\mathrm{CO}$ and $\mathrm{CO}_{2}$ formation.

\subsection{Effect in the variation of added carbon}

In the rotary kiln process, in a general way, $5 \%$ of coal is added to the mineral charge, with the purpose to produce reduction reactions of the nickel and iron oxides. In the literature Tanaka et al., (2011) give mention about the good behavior of iron minerals which are reduced when a ratio $\mathrm{C} / \mathrm{O}=1$ is used. Based on this reference, the current thermodynamic analysis considers mixtures of lateritic mineral with variable proportions of carbon $(3.75-7.59 \%)$ which are equivalent in the $\mathrm{C} / \mathrm{O}$ relation within the interval of 0.66 to 1.0 , such conditions and its effect on a reduction efficiency of the $\mathrm{Ni}$ and $\mathrm{Fe}$ oxides are listed below in the Table 2 .

Content of iron and nickel in form of oxide is very important for the processing of these types of minerals. From the thermodynamic analysis of the three samples was observed:

For samples M1 and M2 a reduction percentage around $98 \%$ was obtained for the iron. These samples shown contents of iron of 11.40 and $13.78 \%$ and nickel of 2.04 and $1.78 \%$, with a $\mathrm{C} / \mathrm{O}$ ratio $=0.92$ and 0.78 , respectively.
Sample M3 had an iron reduction of $86.9 \%$ with an initial iron content of $16.8 \%$ and nickel of $1.42 \%$, with the adding of $5 \%$ of coal with a $\mathrm{C} / \mathrm{O}=0.66$ ratio.

When the three samples with a ratio $\mathrm{C} / \mathrm{O}=1$ were affected, the reduction of the three samples was $99 \%$. For the sample M1, the nickel reduction was $99.5 \%$ and for the other samples was $100 \%$.

Variation in ratio of $\mathrm{C} / \mathrm{O}$ for each one of the samples is illustrated in Fig. 4. The $\mathrm{C} / \mathrm{O}=1$ ratio produced good results in the iron and nickel oxides reduction. This ratio becomes an important variable, which shall be taken into account in the pyrometallurgical processes of nickeliferous lateritic minerals.

\subsection{Evolution of the equilibrium reactions based on temperature}

In order to evaluate the iron and nickel oxides behavior under reduction conditions, diagrams of equilibrium compositions were made for each sample, based on the temperature within a range of 25 to $1100{ }^{\circ} \mathrm{C}$ and with a ratio $\mathrm{C} / \mathrm{O}=1$. Evidence was given about the feasibility of obtaining metallic iron and nickel with a variable reduction rate based on the temperature.

In Fig. 5 is shown the diagram of equilibrium compositions, this figure shows the evolution of the feasible species based on the temperature. Complete reduction stages of the iron oxides are observed up to the obtaining metallic iron. Additionally, the behavior of the nickel oxide reduction is observed up to the metallic $\mathrm{Ni}$ at an approximately temperature of $430{ }^{\circ} \mathrm{C}$. It is important to indicate that the feed $\mathrm{Ni}$ as oxide is reduced completely, which corroborates the reduction percentages obtained with the $\mathrm{C} / \mathrm{O}=1$ ratio. 
TABLE 2. Behavior of the three lateritic mineral samples with variation of the relation $\mathrm{C} / \mathrm{O}$

\begin{tabular}{lccccccc}
\hline Sample & Oxygen & Coal (\%) & C/O & $\begin{array}{c}\text { Residual } \\
\text { Carbon (\%) }\end{array}$ & $\begin{array}{c}\text { C without } \\
\text { Reaction }\end{array}$ & $\begin{array}{c}\text { Ni Reduction } \\
\text { (\%) }\end{array}$ & $\begin{array}{c}\text { Fe Reduction } \\
\text { (\%) }\end{array}$ \\
\hline M1 & 5.42 & 5.42 & 1.00 & 25.09 & 1.36 & 99.5 & 99.12 \\
& 5.42 & 5.00 & 0.92 & 18.96 & 0.95 & 99.5 & 99.12 \\
& 5.42 & 4.50 & 0.83 & 10.51 & 0.47 & 99.5 & 98.25 \\
& 5.42 & 4.00 & 0.74 & 2.88 & 0.12 & 99.5 & 94.74 \\
& 5.42 & 3.80 & 0.70 & 1.60 & 0.06 & 99.5 & 91.23 \\
& 5.42 & 3.75 & 0.69 & 1.41 & 0.05 & 99.5 & 90.35 \\
& 6.40 & 6.40 & 1.00 & 25.16 & 1.61 & 100 & 99.42 \\
& 6.40 & 6.00 & 0.94 & 20.33 & 1.22 & 100 & 99.42 \\
& 6.40 & 5.00 & 0.78 & 5.78 & 0.29 & 100 & 97.97 \\
& 6.40 & 4.50 & 0.70 & 1.47 & 0.07 & 100 & 92.16 \\
& 6.40 & 4.40 & 0.69 & 1.18 & 0.05 & 100 & 89.99 \\
& 7.59 & 7.59 & 1.00 & 25.03 & 1.90 & 100 & 99.40 \\
& 7.59 & 7.00 & 0.92 & 18.57 & 1.30 & 100 & 99.40 \\
& 7.59 & 5.50 & 0.72 & 1.81 & 0.10 & 100 & 94.64 \\
& 7.59 & 5.30 & 0.70 & 1.15 & 0.06 & 100 & 91.67 \\
& 7.59 & 5.20 & 0.69 & 0.95 & 0.05 & 100 & 90.48 \\
& 7.59 & 5.00 & 0.66 & 0.69 & 0.03 & 100 & 86.90 \\
\hline
\end{tabular}

For this ratio $\mathrm{C} / \mathrm{O}=1,5.42 \%$ of carbon was fed. In Fig. 5 there is also evidence of the presence of residual carbon which corresponds to $25 \%$ of the charge fed, however, it is assumed that this residual carbon percentage does not affect the fusion process nor the product obtained in the arc electric furnace, because in this treatment coke is added for the arc formation and the total iron reduction.

The three samples of iron and nickel reduction data were obtained varying the added coal quantity. This addition was performed at a constant temperature of

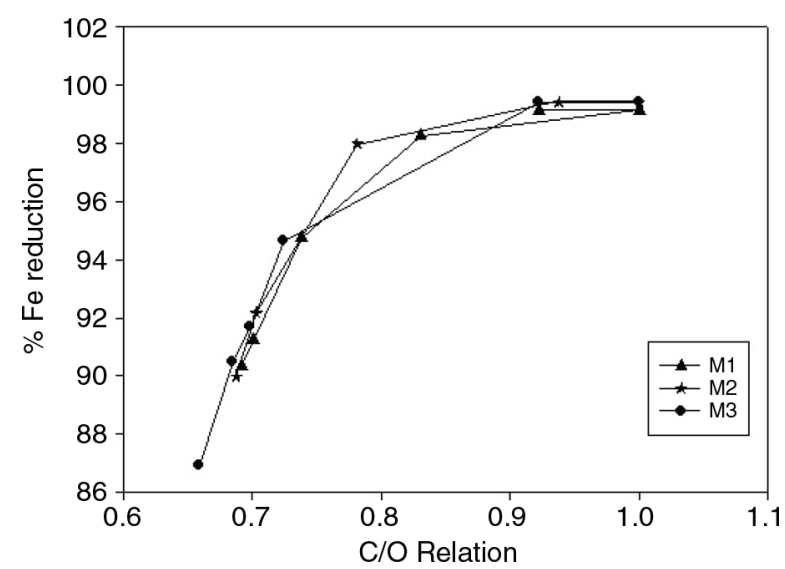

Figure 4. Effect of $\mathrm{C} / \mathrm{O}$ relation on the iron oxide reduction in the lateritic minerals.
$1100{ }^{\circ} \mathrm{C}$. In Table 3 it is observed the variation of the added carbon percentage from $5 \%$ and up to $10 \%$, highlighting that the sample 3 has an iron reduction percentage below $90 \%$ with an addition of the $5 \%$ of carbon. This confirms that it is important to have an excess of carbon which guarantees the carbon monoxide formation and the Boudouard reaction occurs. This is presented in Fig. 5 at $1000{ }^{\circ} \mathrm{C}$. Additionally for calcination-reduction process it is corroborated, that it is an adequate temperature and that the carbon

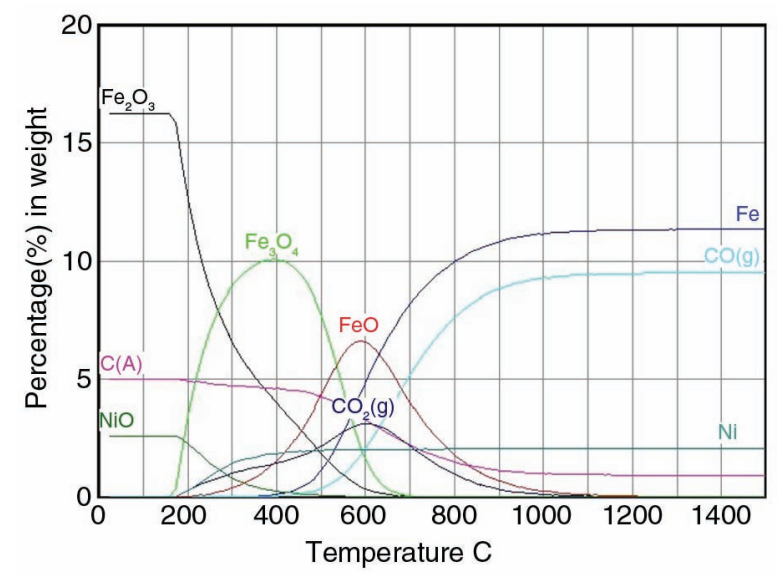

FIGURE 5. Evolution of the equilibrium compositions for M1, with $5.42 \%$ of coal $\mathrm{C} / \mathrm{O}=1$ relation, based on the temperature. 
TABLE 3. Reduction percentage of $\mathrm{Fe}$ and $\mathrm{Ni}$ with the variation in the carbon addition at $1100{ }^{\circ} \mathrm{C}$

\begin{tabular}{llllllllllllllllllll}
\hline Sample & \multicolumn{1}{c}{ M1 } & \multicolumn{1}{c}{ M2 } & \multicolumn{1}{c}{ M3 } \\
\hline C(A)\% & 5 & 6 & 7 & 8 & 9 & 10 & 5 & 6 & 7 & 8 & 9 & 10 & 5 & 6 & 7 & 8 & 9 & 10 \\
Ni Reduction (\%) & 99.8 & 99.8 & 99.8 & 99.8 & 99.8 & 99.8 & 100 & 100 & 100 & 100 & 100 & 100 & 99.8 & 100 & 100 & 100 & 100 & 100 \\
Fe Reduction\%) & 98.9 & 99.2 & 99.3 & 99.4 & 99.4 & 99.5 & 97.8 & 99.3 & 99.5 & 100 & 99.6 & 99.7 & 86.9 & 98.4 & 99 & 99.6 & 99.7 & 99.8 \\
\hline
\end{tabular}

additions made to the three samples were satisfactory for the iron and nickel oxides reduction.

In the reduction processes of the iron minerals must take into account the Boudouard reaction (Eq. (6)):

$$
\mathrm{C}+\mathrm{CO}_{2}(\mathrm{~g}) \longrightarrow 2 \mathrm{CO}(\mathrm{g}), \Delta \mathrm{G} 700{ }^{\circ} \mathrm{C}=-0.015 \mathrm{~kJ}
$$

This reaction take place at $700{ }^{\circ} \mathrm{C}$ with $\Delta \mathrm{G}$ $700{ }^{\circ} \mathrm{C}=-0.015 \mathrm{~kJ}$ which means that the excess of carbon present in the reducer atmosphere and the combination with the $\mathrm{CO}_{2}$, produced during the coal pyrolysis process, where generated $\mathrm{CO}$ at $700{ }^{\circ} \mathrm{C}$ and where the increases temperature, is factible the formation and chemical stability of this compound.

The carbon excess is stoichiometric, and it is the necessary for take place the Boudouard reaction, this is obtained with the relation $\mathrm{C} / \mathrm{O}=1$.

Figure 6 illustrates the behavior of the lateritic minerals in a general way at $1100{ }^{\circ} \mathrm{C}$, varying the carbon additions given in percentage in weight with a calculation base of $100 \mathrm{~kg}$ in the mixture, highlighting that the iron oxide reduction stages occur starting from hematite and obtaining preponderantly metallic iron. It is also observed that the nickel is reduced completely, with a $100 \%$ of its recovery. Figure 6 gives evidence of feasibility of the iron and nickel oxides reduction for the treatment of lateritic minerals by pyrometallurgical route with nickel contents below $2 \%$.

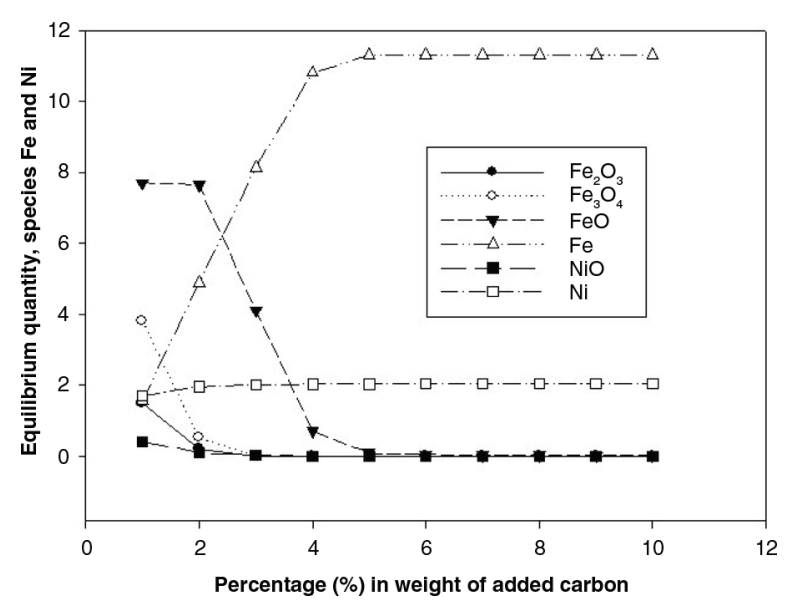

FIGURE 6. Evolution of equilibrium composition in a lateritic mineral sample with the addition of variable quantities of carbon.

\section{CONCLUSIONS}

- A thermodynamic analysis of the reduction of three samples of Colombian nickeliferous lateritic minerals was conducted with nickel contents of $2.04 \%, 1.78 \%$ and $1.42 \%$. A variation was made in the carbon addition from 3.75 to $7.59 \%$, in order to observe the behavior in the reduction process of the nickel and iron oxides, up to get a $\mathrm{C} / \mathrm{O}=1$ ratio. This ratio showed the best results with a $99 \%$ of reduction of the iron oxides and $100 \%$ of nickel at a temperature of $1100^{\circ} \mathrm{C}$.

- With this thermodynamic analysis is possible to conclude that the Colombian nickeliferous laterites with percentages below $2 \%$ can be processed by pyrometallurgical routes guaranteeing a high nickel recovery in the first stage before obtaining ferro-nickel, alloy used as raw material in the stainless steel industry. It is assumed that the residual carbon does not affect the fusion process in the arc electric furnace.

\section{ACKNOWLEDGMENTS}

The authors wish to thank the Universidad Nacional de Colombia for the support given in the characterization of the minerals, the Universidad Autónoma de Coahuila, Mexico for its collaboration in the handling of the software and Universidad Pedagógica y Tecnológica de Colombia for its collaboration in the achievement of the samples.

\section{REFERENCES}

Dalvi, A.D., Bacon, W.G., Osborne, R.C. (2004). The Past and the Future of Nickel Laterites, PDAC 2004 International Convention, Ontario, Canada, pp. 1-27. http://www.pdac.ca/ docs/default-source/publications - papers-presentationsconventions/techprgm-dalvi-bacon.pdf?sfvrsn $=4$.

Girgin, İ., Obut, A., Üçyildiz, A. (2011). Dissolution behaviour of a Turkish lateritic nickel ore. Miner. Eng. 24 (7), 603-609. http://doi.org/10.1016/j.mineng.2010.10.009.

Huang, Q., Lv, X. (2011). Phases transformation of nickel lateritic ore during dehydration. J. Min. Metall. Sect. B- 47 (1), 45-51. http://doi.org/10.2298/JMMB1101045H.

Li, S. (1999). Study of Nickeliferrous Laterite Reduction. Thesis Master of Engineering, McMaster University, Ontario, Canada. https://macsphere.mcmaster.ca/bitstream/11375/ 11804/1/fulltext.pdf.

Oxley, A., Barcza, N. (2013). Hydro-pyro integration in the processing of nickel laterites. Miner. Eng. 54, 2-13. http:// dx.doi.org/10.1016/j.mineng.2013.02.012. 
Pickles, C.A., Harris, C.T., Peacey, J., Forster, J. (2013). Thermodynamic analysis of the $\mathrm{Fe}-\mathrm{Ni}-\mathrm{Co}-\mathrm{Mg}-\mathrm{Si}-\mathrm{O}-\mathrm{H}-\mathrm{S}-\mathrm{C}-\mathrm{Cl}$ system for selective sulphidation of a nickeliferous limonitic laterite ore. Miner. Eng. 54, 52-62. http://doi.org/10.1016/j. mineng.2013.03.029.

Ramírez, A.C., Serrano, A.R., Salinas, E.R., López, A.R., Ramírez, M.V. (2008). The solubility and activity determination of $\mathrm{NiO}$ in the $\mathrm{SiO}_{2}-\mathrm{NiO}-\mathrm{FeO}$ system. J. NonCryst. Solids 354 (30), 3533-3539. http://doi.org/10.1016/j. jnoncrysol.2008.03.027.

Rao, M., Li, G., Jiang, T., Luo, J., Zhang, Y., Fan, X. (2013). Carbothermic Reduction of Nickeliferous Laterite Ores for
Nickel Pig Iron Production in China: A Review. JOM 65 (11), 1573-1583. http://doi.org/10.1007/s11837-013-0760-7.

Rodríguez, R., Londoño, J., Garzón, E., Forero, J., Manrique, J., Rojas, W. (2009). Níquel en Colombia. Unidad de Planeación Minero Energética, Bogotá, Colombia. http://www. upme.gov.co/Docs/Niquel_Colombia.pdf.

Tanaka, Y., Ueno, T., Okumura, K., Hayashi, S. (2011). Reaction Behavior of Coal Rich Composite Iron Ore Hot Briquettes under Load at High Temperatures until $1400^{\circ} \mathrm{C}$. ISIJ Int. 51 (8), 1240-1246. http://jlc.jst.go.jp/JST.JSTAGE/ isijinternational/51.1240. 